\title{
Unconditional Federal Transfers and State Government Spending: An Investigation of the Flypaper Effect in Nigeria and South Africa
}

Abdurrahman Isik

Nile University of Nigeria

Peter D. Golit

Central Bank of Nigeria

Paul Terhemba lorember ( $\nabla$ piorember1990@gmail.com )

Nile University of Nigeria https://orcid.org/0000-0002-3092-2378

\section{Research Article}

Keywords: Unconditional Federal Transfers, State Spending, Flypaper Effect, Two-Step System GMM, Nigeria, South Africa

Posted Date: February 11th, 2022

DOI: https://doi.org/10.21203/rs.3.rs-1117690/v1

License: (a) (1) This work is licensed under a Creative Commons Attribution 4.0 International License. Read Full License 


\title{
Unconditional Federal Transfers and State Government Spending: An Investigation of the Flypaper Effect in Nigeria and South Africa
}

\author{
Abdurrahman Isik ${ }^{1}$, Peter D. Golit ${ }^{2}$, Paul Terhemba Iorember ${ }^{1 *}$ \\ ${ }^{1}$ Department of Economics, Nile University of Nigeria, Abuja, Nigeria \\ ${ }^{2}$ Department of Economics, Nile University of Nigeria, Abuja, Nigeria \\ Research Department, Central Bank of Nigeria, Abuja, Nigeria \\ ${ }^{1}$ Department of Economics, Nile University of Nigeria \\ * Corresponding Author Email: piorember1990@gmail.com
}

\begin{abstract}
The "flypaper effect" is undoubtedly one of the most interesting concepts associated with the spending behaviors of subnational governments. Yet, empirical evidence on it in the Sub-Saharan Africa (SSA) is scarce. The current study is the first attempt at providing empirical evidence on the existence of the flypaper effect in the two largest economies in SSA. Employing the two-step system GMM estimator, our findings suggest that the provincial governments in South Africa are more responsive to positive changes in unconditional federal transfers than the state authorities in Nigeria, in terms of providing a higher volume of public goods and services. It is, thus, our submission that public sensitization on the amounts of unconditional federal transfers received by the state governments and their disbursements needs to be adequately enhanced in order to reduce the illusion level or information asymmetry surrounding the use of unconditional federal transfers if the public at the state level is to immensely benefit from the continued flow of unconditional federal transfers from the central to the state governments.
\end{abstract}

Key Words: Unconditional Federal Transfers, State Spending, Flypaper Effect, Two-Step System GMM, Nigeria, South Africa 


\section{Introduction}

Since the early 1970s, the fiscal federalism literature anticipates the impact of a lumpsum transfer on subnational government expenditure to remain the same with the effect of an identical increase in taxpayers' income (Sour, 2013). This prediction is, however, not supported by recent empirical evidence, as recent findings reveal that increase in intergovernmental transfers is more impactful on subnational expenditure than equivalent increases in taxpayers' income (Bradford and Oates, 1971). The above phenomenon in which intergovernmental transfers tend to induce more local spending than do equivalent increases in subnational income is known as the flypaper effect in the public finance literature (Turnbull, 1998). The concept of the flypaper effect also corresponds to the long-held view that "money sticks where it hits", signifying that money transferred to the public sector often stays in the public sector, while money transferred to the private sector tends to remain within the private sector (Fisher, 1982; Inman, 2008). The flypaper effect also describes a situation where an increase in central government grant improves local spending of a subnational government more than the increase induced by an equivalent rise in local revenue (Tanjunga, et al., 2021). Empirical evidence abounds in the extant literature on the existence of the flypaper effect in various countries [Logan, 1986; Wyckoff, 1988; Grossman, 1990; Dollery and Worthington, 1995; Gamkhar, 2000; Knight, 2002; Sağbaş \& Saruç, 2007; Dahlberg et al., 2008; Singhal, 2008; Espinosa, 2011; Brollo et al., 2013; Sour, 2013; Ferede and Islam, 2015; Allers and Vermeulen, 2016; Baskaran, 2016; Langer \& Korzhenevych, 2019; Cruz and Silva, 2020].

A number of studies have also attempted to know whether the response of public spending to unconditional federal transfers is symmetric or not. In other words, does public spending respond in the same manner to positive and negative changes in unconditional federal transfers? The two categories of asymmetry of the flypaper effect identified in the extant literature are the fiscal replacement and the fiscal restraint paradigms (Sour, 2013). The fiscal replacement category occurs when there is a reduction in federal transfers, but the local authorities prefer to keep public spending at the same level by generating more taxes or growing the local public debt ${ }^{1}$.

\footnotetext{
${ }^{1}$ See Heyndels (2001) and Melo (2002) for further information.
} 
The fiscal restraint asymmetry occurs when the local authorities choose to reduce public spending by a bigger margin than would have been the case for a symmetric response.

Sour (2013) further indicates that subnational governments are exposed to a greater burden of tax collection under the fiscal replacement category in comparison to the lesser burden imposed by the symmetric case; while the tax burden placed by the fiscal restraint category is the least. It is also observed that the extant literature is deficient of information on why the different types of asymmetry exist, except for the exposition about the fiscal replacement paradigm that some political factors are responsible for the difficulty faced by political leaders at the local level to cut down or possibly eliminate public programmes that have already taken root when faced with dwindling federal transfers (Gramlich, 1987).

Many subnational governments were found to exhibit asymmetric fiscal replacement behaviors in response to unconditional federal transfers [Benton, 1992; Gramlich, 1987; Deller and Walzer, 1995; Heyndels, 2001; Melo, 2002; Levaggi and Zanola, 2003; Shaw, 2005; Deller and Maher, 2006; Pallesen, 2006; Trujillo, 2006]². Becker (1996), however, observed the sensitivity of the flypaper effect to model specification, noting that a potential endogeneity problem may result from the unobservable characteristics of the cross-sections such that the coefficient estimate of the transfer variable may be bias $^{3}$. Hamilton (1983), Hines and Thaler (1995) also expressed doubts on the existence of the flypaper effect, citing procedural and measurement errors as reasons for the misleading results. The evidence emerging from the crosscountry empirical literature is also mixed but with a larger majority of the results supporting the existence of the flypaper effect.

The major problem with unconditional federal transfers in Nigeria and South Africa, as in many other countries of Sub-Saharan Africa (SSA), is that the subnational governments tend to over-depend on such transfers to finance their budgets without making any meaningful efforts to generate their own revenue. Furthermore, the over-

\footnotetext{
2 See Sour (2013) for details.

${ }^{3}$ Knight (2002) and Gordon (2004) established that the flypaper effect vanishes when instrumental variables are used to account for the endogeneity problem.
} 
reliance on such transfers tends to soften the budget constraint of the subnational governments due to failure of the local authorities to sufficiently internalize the cost of spending, and also because large vertical imbalances are likely to generate bailout expectations that tend to give a false impression that the central government would always come to the aid of the subnational governments in the event that they run into a fiscal crisis (Eyraud and Lusinya, 2013). These expectations tend to push the subnational governments to increase spending even when there is no corresponding increase in their internally-generated revenue (IGR).

The recent debates on the reform of fiscal decentralization in these countries have, therefore, centered on the devolution of more fiscal powers to the subnational governments in order to enhance their taxing powers and align their taxes with expenditure responsibilities. What is clear from the above discussion is that the financing structure of the subnational governments in Nigeria and South Africa is skewed in the direction of unconditional federal transfers more than IGR. This also suggests that federal transfers are contributing more to subnational spending than IGR, thus signaling the existence of the flypaper effect in the spending behaviors of the subnational governments.

The "flypaper effect" is undoubtedly one of the most interesting concepts associated with subnational spending. Though many scholars have tested for its presence in advanced and emerging markets, the literature on developing countries remains very scanty and the evidence is largely mixed. We have not, to the best of our knowledge, come across any empirical study that has tested for the flypaper effect in SSA. This is why we have undertaken to contribute to the subsisting debate by examining the evidence for the two largest economies in SSA (Nigeria and South Africa) as to whether the transfer of revenue resources from the centre to the state (or provincial) governments induces a stronger response in public spending than the impact created by comparable increases in private incomes.

We shall, therefore, attempt to answer the following research questions: Does the flypaper effect exist for the state and provincial governments in Nigeria and South Africa? If yes, do the state authorities in Nigeria respond to increase in unconditional 
federal transfers the same way as the provincial governments in South Africa? The objectives of the study, therefore, are to: First, investigate the existence or otherwise of the flypaper effect in Nigeria and South Africa. The second objective is to examine whether the state authorities in Nigeria and the provincial governments in South Africa respond to an increase in unconditional federal transfers in exactly the same manner.

Our major contributions to the public finance literature on the flypaper effect are, thus, threefold: The study is the first attempt to provide empirical evidence on the existence or otherwise of the flypaper effect in Nigeria and South Africa, thereby, attesting to its originality. Secondly, the study differs from the past attempts in other jurisdictions in terms of the choice of estimation technique and empirical coverage. Unlike in the past, we undertake a comprehensive analysis of the flypaper effect in the two countries using a superior estimation technique, the two-step System Generalized Method of Moments (SGMM) that is robust to heteroscedasticity and autocorrelation, while at the same time addressing the endogeneity problems that are inherent in the estimation of the flypaper effect.

We have not, to the best of our knowledge, come across any study that investigates the existence of the flypaper effect at the state or provincial level in Nigeria and South Africa on a country by country basis, while at the same time providing a comparative analysis of the two leading economies in Sub-Saharan Africa. Our intention here is to enhance precision of the parameter estimates beyond the levels achieved in the past in order to compare the results with those of other estimators used in the past studies.

Our empirical results indicate a stronger response of public spending to unconditional federal transfers than to private income, suggesting the presence of the flypaper effect in both Nigeria and South Africa. Our results further indicate that the outcomes are sensitive to model specifications and choice of estimation technique.

The paper is organized into five sections. Following the introduction is section two which provides a theoretical background to the flypaper effect and the structure of unconditional federal transfers in Nigeria and South Africa. Section three discusses 
the methodology. The empirical results are presented and discussed in section four, while section five provides the concluding remarks and policy options.

\section{Literature and Theoretical Review}

\subsection{The Flypaper Effect in Theory}

The theoretical basis for the flypaper effect was first provided by Bradford and Oates (1971) who hypothesized that the "effect on the allocation of the public budget between private and public goods is the same whether there is a transfer from the federal to the local government or if the transfer is made directly to the individuals" Sour $(2013)^{4}$. The empirical studies that later tested the above hypothesis, however, discovered that the response of public spending to intergovernmental transfers was more than the response to increases in private personal income. This implies that the transfer of revenue resources to local authorities yields more effect on public goods than was earlier predicted in theory, such that the programmes implemented with the aid of intergovernmental transfers tend to persist even when the transfers are no longer coming. The continuing discovery of the same result was what caused the public finance literature to consider it as an anomaly and a purely empirical phenomenon which was first referred to as the flypaper effect by Arthur Okun, who compared it with a paper enclosing some sticky glue that is used in some communities to kill insects or rodents (Sour, 2013) $)^{5}$.

The bureaucratic behavior of the local authorities is tailored towards maximizing the government budget which is the direct reflection of the taxpayers' preferences on public spending, without which the citizens will not vote for the government (Niskanen, 1968). The government budget is maximized at the point of equilibrium where the budget is equal to (or greater than) the minimum cost of supplying the required level of public goods. In the attempt to maximize the local budget, the local authorities are assumed to behave like a monopolist by supplying the public goods only in exchange for the total budget and not at idiosyncratic rates. This gives the

\footnotetext{
${ }^{4}$ See Hines and Thaler (1995) for further exposition

${ }^{5}$ This is why the public finance literature has described the flypaper effect as "money sticks where it hits" (Hines and Thaler, 1995).
} 
local government a form of market power in such a way that enables it to make an "all or nothing" decision (Sour, 2013).

On the basis of the above assumptions, Acosta and Loza (2001) in Sour (2013) postulated that the preferences of bureaucratic governments and those of individuals in the community are quasi-linear, thereby allowing for a mathematical derivation of the flypaper effect as follows: Let "E" represents the level of government expenditure and "Y" the private income of individuals in the community, with " $g$ " as the portion of public good provided through intergovernmental transfers. The model postulates that: (A) The change in public expenditure arising from a change in intergovernmental transfers is positive. That is $\frac{\partial E}{\partial g}>0$. (B) The change in public expenditure arising from a change in private income of individuals in the community is positive. That is $\frac{\partial E}{\partial Y}>0$. Thus, the flypaper effect is said to exist whenever the impact of intergovernmental transfers on public expenditure is higher than the impact of private income of individuals in the community: That is: If $\frac{\partial E}{\partial g}>\frac{\partial E}{\partial Y}$ then there is Flypaper Effect.

\subsection{The Structure of Unconditional Federal Transfers in Nigeria and South Africa}

\section{Unconditional Federal Transfers in Nigeria}

Nigeria first transited from a regional to a federal system of government in 1967 during which it reconstituted the existing four regions into a three-tier structure comprising the federal, state and local governments. Following the growing agitations for regional and ethnic balance in the governance process, the 12 state structure initially established in 1967 was restructured in 1996 into the current 36 state structure and a federal capital territory which shares the status of a state government. The federal system assigns responsibilities among the three tiers of government in line with the provisions of the 1999 constitution. The federal government is solely responsible for the functions listed under the exclusive legislative list, but is jointly responsible with the state governments for overlapping functions that are listed under the concurrent legislative list (See Appendix 1 for the assignment of responsibilities as enshrined in the 1999 constitution of the Federal Republic of Nigeria). 
The federal government collects, on behalf of the federation, oil and non-oil revenue (including main taxes) and remit into the federation account for distribution among the three tiers of government. The sharing of revenue from the federation account is based on a vertical formula that allocates 87.0 percent of the federally-collected revenue to the three tiers of government after deducting the 13 percent allocation to oil producing states based on an existing derivation principle on mineral revenue. The vertical revenue allocation formula stipulates 52.7, 26.7 and 20.6 percent of the revenue available for distribution in favour of the federal, state and local governments, respectively. The vertical revenue allocation formula for Nigeria from 1960 to date is reported in Appendix 2).

The Federation Account, which is the source of unconditional federal transfers to the three tiers of government, comprised largely of revenue proceeds from crude oil and gas exports, customs and excise duties, petroleum profits tax and royalties, domestic crude oil sales and corporate income tax. The Joint Venture Cash call (JVC) is the share of oil production cost borne by the government of the federation under the production sharing agreement signed with the joint venture partners. It is normally deducted from total oil revenue as a first line charge before the balance is remitted into the Federation account for distribution.

The first line charges on non-oil revenue are the 7 percent and 4 percent deductions in favour of the Federal Inland Revenue Service (FIRS) and the Nigeria Customs Service (NCS) as costs of collections for the revenue collection agencies. The other first line charges that have been recently subsumed under the federal government share include statutory allocations to the National Judicial Council (NJC), Universal Basic Education (UBE) and Special Funds for the development of mineral production areas, general ecology and statutory stabilization. The Value Added Tax (VAT) revenue which accrues into the VAT Pool Account is also distributed among the three tiers tiers of government in accordance with the vertical sharing formula of 15,50 and 35 percent in favour of the federal, state and local governments, respectively (See Appendix 3 for details). 
The components of state governments' own revenue include the personal income tax, road taxes, business registration fees, stamp duties and fees on land and property leasing. On the other hand, the own revenue of local governments come from fees and levies imposed on motor parks, markets, slaughter houses, public conveniences health services; as well as the registration of births, deaths and marriages. Though the federal government determines the rates on major taxes and the tax bases, the rates/bases on fees and local taxes/levies are under the purview of the state and local governments, excluding VAT.

The indices used for horizontal revenue allocation among the state governments include population $(30 \%)$, internal revenue efforts $(10 \%)$, land mass/terrain $(10 \%)$; equality of states $(40 \%)$ and social development indicators $(10 \%)$. The $10 \%$ social development indicator is further broken down into the following six indices: primary school enrolment (24\%); number of hospital beds (30\%), quantity of rainfall (15\%), direct number of students enrolled in secondary schools $(8 \%)$; access to clean water $(15 \%)$ and the inverse of number of students enrolled in secondary schools (8\%). See Appendices $4 \mathrm{a}$ and $4 \mathrm{~b}$ for details of horizontal revenue allocation among the state governments in Nigeria. The constitution further provides for a 'Joint Account' where the allocation to the local governments from the Federation Account and $10.0 \%$ of the internal revenue of a given state should be remitted for distribution among the local governments in the state. The indices used for the horizontal allocation of VAT revenue to the state and local governments include equality (50\%), derivation or origin (20\%) and population (30\%).

\section{Unconditional Federal Transfers in South Africa}

It was not until after the collapse of the apartheid administration in 1994 that South Africa began to witness improvements in fiscal decentralization. Fiscal decentralization was not very effective in the apartheid era because the country operated a purely unitary system that was largely characterized by racial discrimination, social strife and rising agitations for self-determination. But, with the advent of democratic governance in 1994, the unitary system was replaced by a more federal-like system with a three tier structure - the national, provincial and municipal governments. The improvements in fiscal decentralization from 1994 was, thus, not 
based on any sound economic justification but was borne out of negotiations and cooperation among the political leaders in order to eradicate unnecessary conflicts.

The country now has a total of 9 provinces with 8 metropolitan, 44 districts and 226 local municipalities. The municipalities are grouped into metropolitan and district municipalities with each district municipality having various local municipalities. Policy initiatives and strategic development goals are handled at the national level with responsibilities and standards set for the provinces and municipalities to function effectively. However, the national government still monitors the lower levels of government in order to ensure the effective implementation of concurrent functions.

The concurrent functions provided in the constitution for the national and provincial governments include education, housing, health and welfare with the policy formulation vested in the national government while the implementation is to be handled by provincial governments. Road construction in provincial areas are, however, the exclusive preserve of provincial governments while basic services such as sanitation, streetlights, access/feeder roads and general town planning are left in the hands of local governments (Hobdari, et al., 2018). The country operates a unified public service structure for the national and provincial governments with the remunerations harmonized for government employees that belong to the same grade level. The national public service does not include government employees at the local level, yet local employees still enjoy comparable remunerations because of the influence of labour unions that often help to achieve convergence in salary payments.

The revenue assignments are in line with international best practice as the national government is given the sole responsibility to adjudicate over VAT, corporate income tax, customs and excise duties. Fuel levy and personal income tax are within the purview of provincial governments, though they are still subject to consultations with the national authorities in order to safeguard the national interest. The municipal governments are empowered with more tax handles than the provincial governments as they are authorized to collect property taxes and user charges on water supply and electricity. The share of taxes in provincial own revenue is low (just about 3\%) with the large revenue gaps at the provincial level filled by central transfers. This leaves the provincial governments with low fiscal space to make spending decisions. 
However, the municipalities enjoy much fiscal autonomy as more than 90 percent of their revenue comes from fees on public utilities and property taxes, thereby enabling them to make wide-ranging spending allocation decisions with the central government providing oversight function.

The subnational governments in South Africa enjoy two major types of transfers, earmarked transfers and equitable share transfers. About 80 percent of the transfers to provincial governments come in the form of equitable share transfers (which are unconditional transfers), though this category of transfers only accounts for about 50 percent of the transfers to municipalities, which is inclusive of their share of general levy usually shared between metropolitan and other municipalities. Population is the major index used in arriving at the formula for sharing the two categories of transfers and these transfers are shared on the basis of a transparent formula that is always updated every five years with the aid of census survey data. National revenue estimates, however, provide the basis for equitable share transfers to the provincial and municipal governments. About 48 percent of the 2015/16 budget appropriations went to the national government with only about 43 percent and 9 percent going to provincial and the municipal governments. This sharing excludes the amount reserved for debt service and contingent liabilities (Hobdari, et al., 2018).

As from 2014/2015, the horizontal formula for equitable share transfers to the provincial governments is based on the following indices: education (48\%); health (27\%), basic component (16\%) based on each province's share of national population; institutional component (5\%) divided equally among the provinces; poverty component $(3 \%)$ derivable from income data, thus reflecting the re-distributive character of the formula; output component $(1 \%)$ which relies on regional gross domestic product regularly published by Statistics South Africa. The horizontal formula for equitable share transfers to the local governments consists of five components that are categorized into three parts. The first part is the basic services component (which provides for free basic services to poor households). The second part consists of three components: the institutional component (which provides subsidy for basic administrative costs); the community services component (which provides core municipal services that are excluded from basic services); the revenue 
adjustment factor (which provides for municipalities with limited fiscal capacity). The third is the correction and stabilization factor, which provides for predictability and stability in meeting the guarantees provided for in the formulas (Hobdari, et al., 2018).

The provincial governments also benefit from conditional grants which come in four different types: the first are general grants designed to provide funding support to programs and projects that are co-funded by provincial governments such as infrastructural development. The second are specific grants designed to meet the central government's responsibilities in financing programs and projects being implemented by the different provincial governments. The third are allocations-inkind which refer to non-monetary grants by departments and agencies of the central government to implement public projects in the different provinces. The fourth category of grants is designed to support the provincial governments in addressing natural disasters.

\section{Data and Methodology}

\subsection{Data}

We employ two separate annual panel datasets to examine the impact of unconditional federal transfers and private personal income on expenditure of the state/provincial governments in Nigeria and South Africa towards verifying the existence or otherwise of the flypaper effect in the two countries for the period 2013-2020. Following the literature, we use per-capita revenue (own-revenue/population) of the state/provincial governments as proxy for private personal income since historical data on private income are not available at the state/provincial level in Nigeria and South Africa. The first dataset is a sample of 22 out of the 36 state governments in Nigeria (including the federal capital territory which shares a similar status with the state governments), while the second dataset consists of a population of 9 provinces in South Africa. This reflects a sample of 176 observations for Nigeria and a population of 72 observations for South Africa. The selection of the states in Nigeria and the study period was based on the availability of relevant data. The selected states cut across all geopolitical zones in the country, implying that the sample is representative of the entire population of the state governments. 
The data on unconditional federal transfers (UFT), total revenue (TR), own revenue $(\mathrm{OWN})$ and total expenditure (TE) of the state governments in Nigeria are from various editions of the Central Bank of Nigeria (CBN's) Annual Economic Report and the CBN's Statistical Bulletin. However, the data on GDP deflator are from the online database of the International Monetary Fund (IMF's) World Economic Outlook, while the estimated state population (POP) is from the National Bureau of Statistics (NBS). The data on public school enrollment come from the online databases of the Federal Ministry of Education (FMF), Universal Basic Education Commission (UBEC) and the National Bureau of Statistics (NBS), with minor interpolations to cover data gaps.

On the other hand, the data on equitable (unconditional or non-matching) transfers (UFT), own revenue (OWN) and total expenditure (TE) of the provincial governments in South Africa are from the online databases of the National and Provincial Treasuries. The data on Gross Domestic Product (GDP) deflators are from the International Monetary Fund (IMF's) World Economic Outlook, while the estimated provincial population (POP) is from the online databases of Statistics South Africa and the Provincial Treasuries. The data on public school enrollment are, however, from the online database of the National Treasury.

\subsection{Econometric Model}

To explore the existence of the flypaper effect, we express the following dynamic panel regression model with endogenous regressors to capture the response of the state or provincial spending to unconditional federal transfers and private personal income. The model controls for unobserved group-specific effects.

$\ln T E_{i t}=\alpha_{0}+\Phi \ln T E_{i t-1}+\beta_{1} \ln U F T_{i t-1}+\beta_{2} \ln P P I_{i t-1}+\omega_{i}+\delta_{t+} \gamma \ln X_{i t}+\mu_{i t}$ (4.1)

Where:

$i$ represents the number of cross-sections $[i=1, \ldots, 22$ states in the case of Nigeria and $1, \ldots, 9$ provinces in the case of South Africa]; $t$ denotes the number of time series (or years). $\ln T E_{i t}$ is the natural logarithm of public expenditure for state or province $\mathrm{i}$ in year t. $\ln U F T_{i t}$ stands for the natural logarithm of unconditional federal transfers for 
state/province $\mathrm{i}$ in year t. $\ln P P I_{i t}$ represents private personal income proxied by per capita own revenue for state or province $\mathrm{i}$ in year $\mathrm{t}$; $\ln X_{i t}$ is a vector of control variables reflecting public school enrollment (InPSE) and year dummies included in the model to circumvent the problem of omitted variable bias or model underfitting. $\beta_{0}$ is the intercept term for country $\mathrm{i}$ in year t. $\Phi, \beta_{1}$ and $\beta_{2}$ are the elasticities of state or provincial expenditure to a one percent change in the one-period lag of the dependent variable, unconditional or non-matching federal transfers and private personal income, respectively. $\omega_{i}$ and $\delta_{t}$ denote unobserved state/provincial-fixed effects and year-fixed effects in that order. $\mu_{i t}$, however, represents time and statespecific error term.

The lagged log of public spending $\left(\ln T E_{i t-1}\right)$ and non-matching federal transfers ( $\left.\ln U F T_{i t-1}\right)$ are the endogenous variables in the model, the log of public school enrollment ( $\ln P S E)$ is treated as weakly exogenous; while the log of private personal income $\left(\ln P P I_{i t}\right)$ and the year dummies are strictly exogenous. The instrumental variables used in the model are one-period lag of the state/provincial spending $\left(\ln T E_{i t-1}\right)$ for the GMM instrument, with the $\log$ of public school enrollment ( $\ln P S E)$, the log of private personal income $(\ln P P I)$, the log of total revenue $(\ln T R)$ of the state and provincial governments and the log of the state or provincial population $(\ln P O P)$ as other instruments.

It is important to note that the impact of the regressors on the dependent variable in both the short and long-run cannot be measured via the use of a static model, which is why we employ a dynamic panel regression model to be estimated by the two-step SGMM estimator in order to reflect the persistent feature of the state/provincial spending while at the same time resolving the endogeneity problem, omitted variable bias, state/province-specific heterogeneity and measurement errors. We then apply the Hansen J. test of over-identifying restrictions to assess the overall instrument validity and the Arellano-Bond AR(2) specification test to verify that the error terms are serially uncorrelated (Adeleye et al., 2017). 
For us to ascertain the presence of the flypaper effect, we have to compare the response of public expenditure of the state/provincial governments to a one percent increase in unconditional or non-matching federal transfers $\left(\beta_{1}\right)$ and the response of the state/provincial spending to a one percent increase in private personal income ( $\beta_{2}$ ). If $\beta_{1}>\beta_{2}$, then there is evidence that the flypaper effect exists at the state or provincial level in the country being investigated. The flypaper effect is, thus, the estimated difference between $\beta_{1}$ and $\beta_{2}$..

\section{Technique of estimation and justification}

To estimate the model, our study employs the two-step System Generalized Method of Moments (SGMM) estimation technique proposed by Arellano and Bover (1995) and Blundell and Bond (1998) to investigate the flypaper effect in Nigeria and South Africa. The study, thus, departs from the past in the choice of estimation technique for many obvious reasons. The SGMM does not only control for the endogeneity problem in the model, it also controls for omitted variable bias and unobserved panel heterogeneity, as well as measurement errors in the data. The SGMM is also appropriate for dynamic panel models with large number of observations but small time-frame as is the case with our study where the regressors are not strictly exogenous but correlated with the error term; reflecting the inherent presence of the endogeneity problem in the model. The two-stage SGMM is appropriate in such situations where the model exhibits a random walk. Monte Carlo evidence also suggests possible gains in precision in addition to a reduction in small sample bias when the dependent variable is persistent and the time-frame is short (Adeleye, et al. 2017). Embedded in the two-step System GMM estimation technique are two diagnostic tests for instrument validity. These are the Hansen (1982) J. test and the Sargan (1985) test of over-identifying restrictions under a null hypothesis that upholds the overall validity of the instruments used in the model. The Hansen J. test is, however, most often used to test for validity of the instruments. Thus, a failure to reject the null of either of the tests lends credence to the overall validity of the instruments (Adeleye et al. 2017).

\section{Results and Discussions}




\subsection{Descriptive statistics}

Table 1 provides the summary statistics of the data used in the study and the direction of their relationships with the dependent variable (state/provincial expenditure). A cursory look at table 1 indicates that states/provinces receiving larger unconditional federal transfers appear to record larger amounts of public spending.

Table 1: Descriptive Statistics and a priori Expectations

\begin{tabular}{|c|c|c|c|c|c|c|c|c|}
\hline & & \multicolumn{7}{|c|}{ Nigeria } \\
\hline Variables & Obs & Mean & SD & \multicolumn{2}{|l|}{ Min } & Max & \multicolumn{2}{|c|}{ a priori } \\
\hline Total State Expenditure & 176 & $103,417.8$ & $53,520.4$ & \multicolumn{2}{|c|}{$33,081.3$} & \multicolumn{2}{|c|}{$316,338.2$} & na \\
\hline Unconditional Federal Transfers & 176 & $53,032.6$ & $41,504.8$ & \multicolumn{2}{|c|}{$18,370.0$} & \multicolumn{2}{|c|}{$221,800.0$} & + ve \\
\hline Private Personal Income & 176 & $2,517.7$ & $2,049.1$ & \multicolumn{2}{|l|}{375.2} & \multicolumn{2}{|c|}{$20,075.0$} & + ve \\
\hline Public School Enrollment & 176 & 0.688 & 0.621 & \multicolumn{2}{|l|}{0.101} & \multicolumn{2}{|l|}{3.276} & $+\mathrm{ve}$ \\
\hline Total revenue of State Govts. & 176 & $86,296.3$ & $51,377.8$ & \multicolumn{2}{|c|}{$35,442.4$} & \multicolumn{2}{|c|}{313,640} & + ve \\
\hline Total State Population & 176 & 5.4 & 2.3 & 2.1 & & \multicolumn{2}{|l|}{14.5} & + ve \\
\hline & & \multicolumn{7}{|c|}{ South Africa } \\
\hline Total Provincial Expenditure & 72 & $59,993.2$ & $33,149.6$ & $13,165.9$ & & $2,367.2$ & na & \\
\hline Unconditional Federal Transfers & 72 & $47,833.6$ & $27,061.4$ & $9,021.5$ & & $3,370.0$ & $+\mathrm{ve}$ & \\
\hline Private Personal Income & 72 & 295.3 & 81.5 & 133.5 & & 9.5 & $+\mathrm{ve}$ & \\
\hline Public School Enrollment & 72 & 1.403 & 0.787 & 0.283 & & 80 & +ve & \\
\hline Total revenue of State Govts. & 72 & $60,526.5$ & $33,384.6$ & $12,540.6$ & & $2,393.7$ & $+\mathrm{ve}$ & \\
\hline Total State Population & 72 & 6.254 & 3.840 & 1.163 & & 488 & +ve & \\
\hline
\end{tabular}

Note: na = not applicable. +ve denotes a positive relationship between the explained and explanatory variables. Source: Authors' Computation.

Akwa-Ibom state receives the largest amount of non-matching transfers and records the highest amount of state spending. Ebonyi state which receives the lowest amount of unconditional federal transfers also ranks among states with the lowest amounts of public spending (see figure 41 below). 


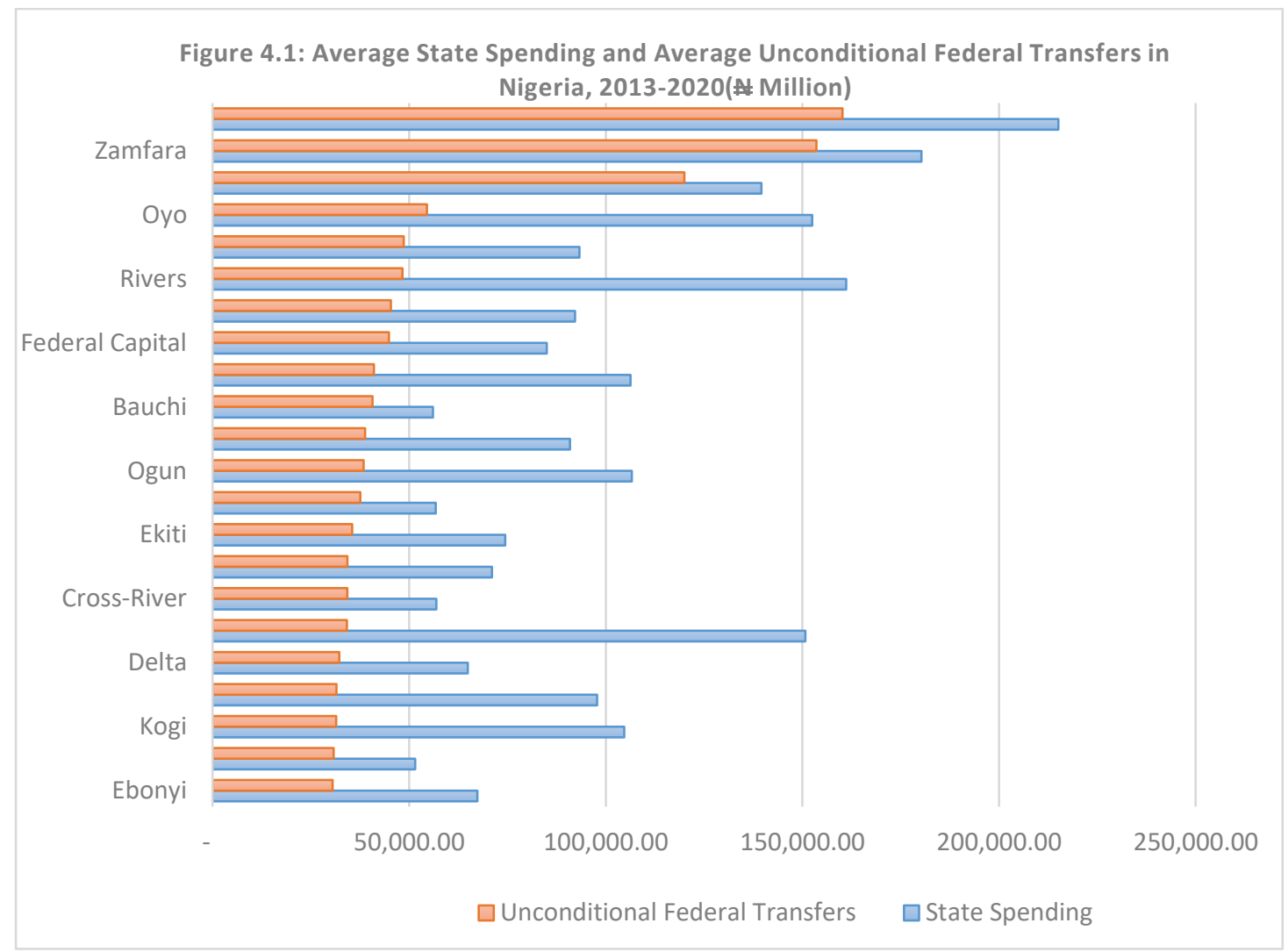

The Province of KwaZulu-Natal which emerges as the highest recipient of unconditional federal transfers in South Africa also records the largest provincial expenditure (see figure 4.2).

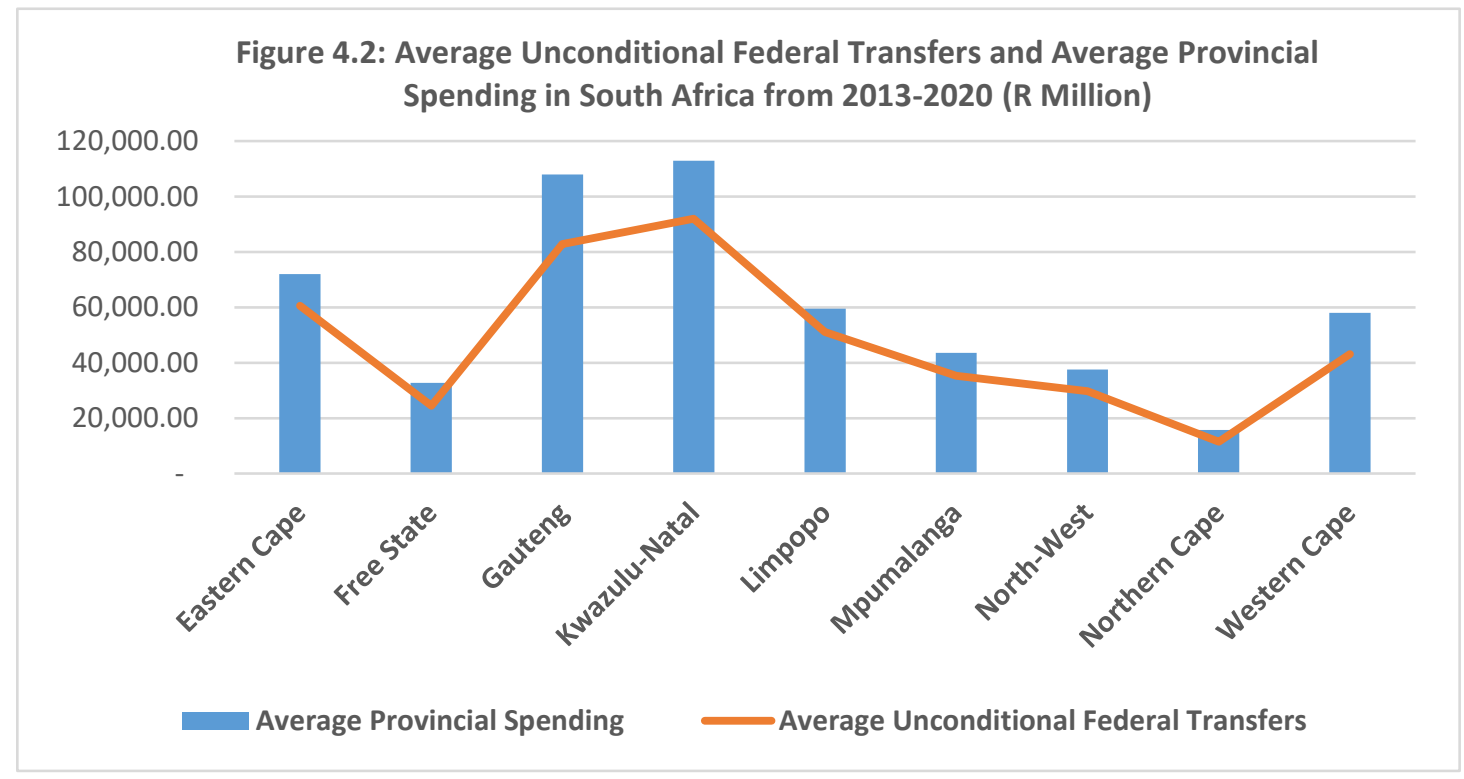


We further observe that states from the South-South (SS) geo-political zone (AkwaIbom, Delta and Bayelsa states) are the largest beneficiaries of unconditional federal transfers in Nigeria and public spending in these states is also among the highest (see figure 4.3 below). This is not surprising since these states receive additional allocation of revenue resources from the Federation Account via the 13 percent derivation principle.

Fig 4.3: Scatter Plot on the Distribution of Unconditional Federal Transfers and Public Spending among Geo-political Zones in Nigeria

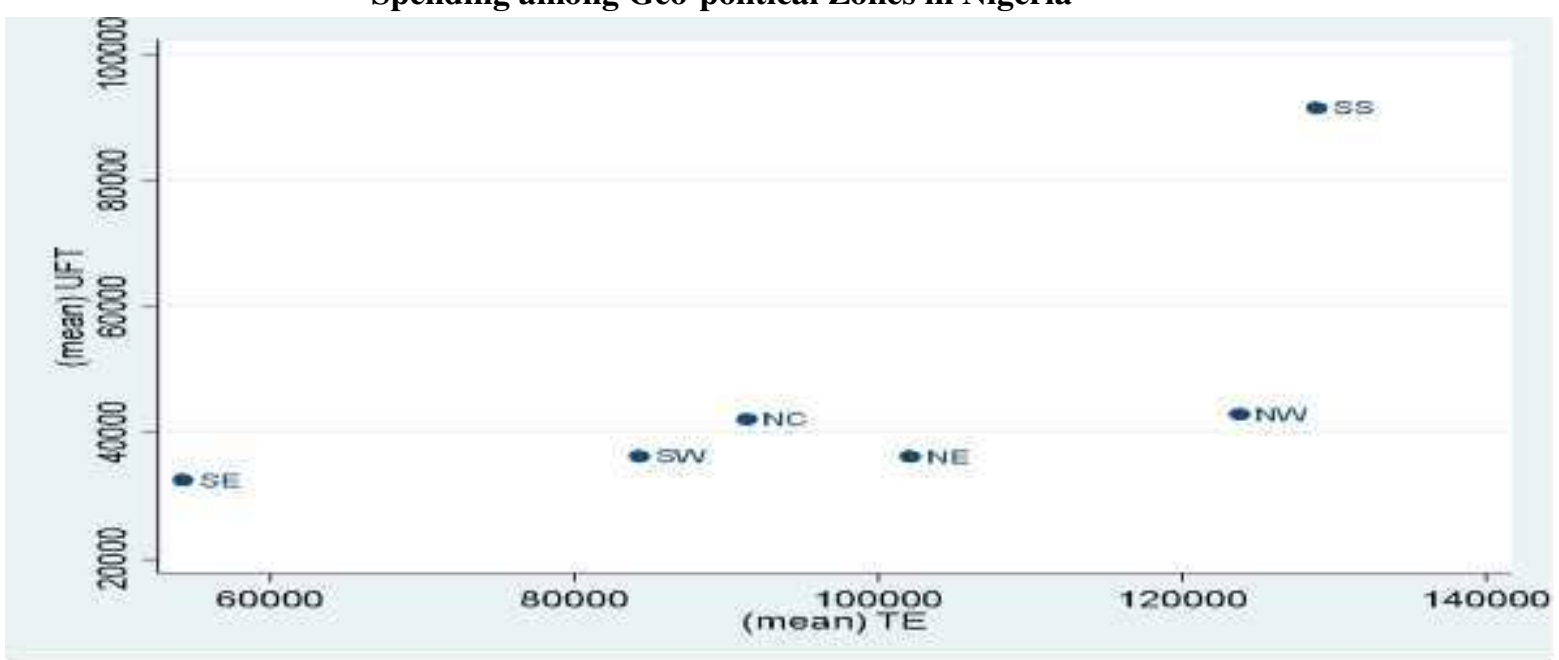

Source: Authors' Computation

States in the South-East geo-political zones receive the lowest amounts of unconditional federal transfers and are also among the least suppliers of public goods at the state level in view of their relatively low public spending. Some states in the North-Central (NC), South West (SW), North-East (NE) and North-West (NW) geopolitical zones also receive low amounts of unconditional or non-matching federal transfers but manage to increase public spending albeit slightly (see figures 4.3 and 4.4).

Fig. 4.4: Scatter Plot on the Distribution of Unconditional Federal Transfers and Public Spending of State Governments in Nigeria 


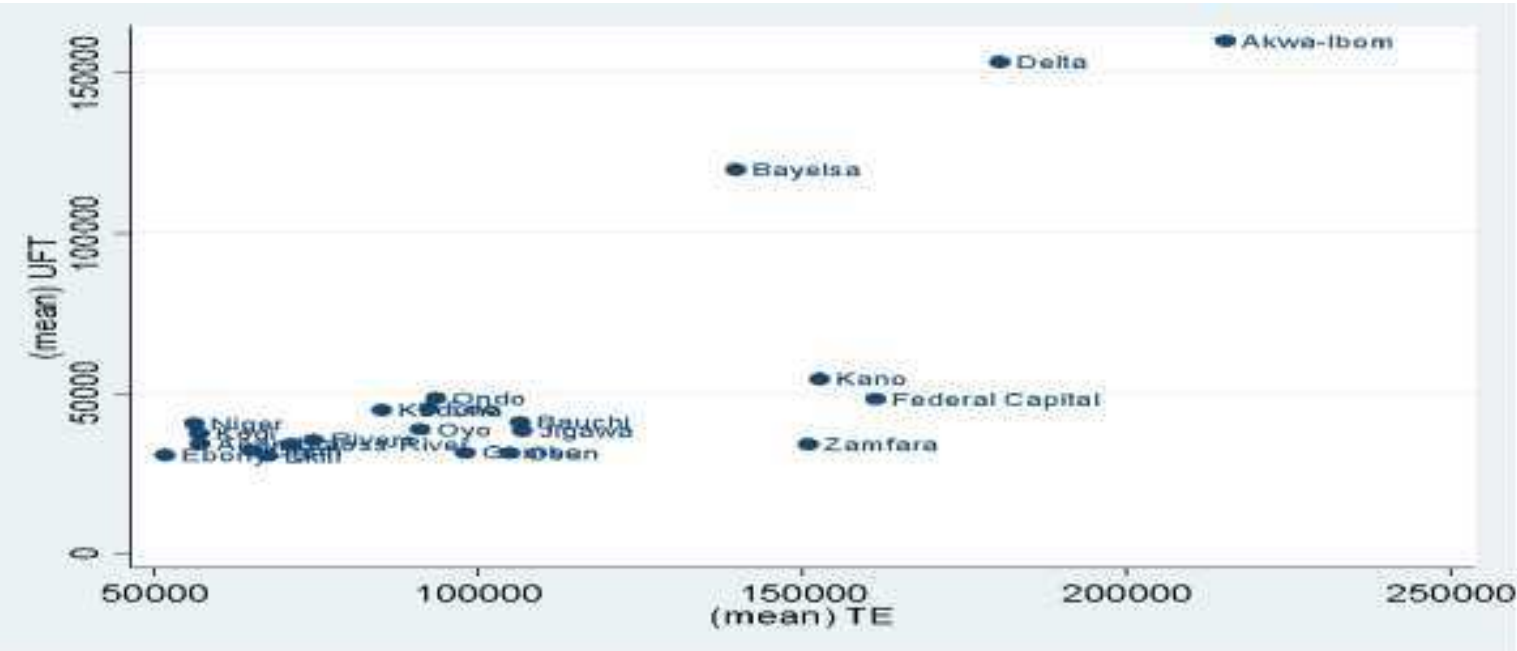

The distribution of unconditional federal transfers among the South African provinces shows that Kwazulu-Natal receives the highest amount of equitable share transfers followed by Gauteng province. Eastern Cape, Limpopo and Western Cape provinces receive moderate amounts of unconditional federal transfers. Mpumalanga, Free State and North West provinces are among the lowest recipients of non-matching transfers in South Africa with the Northern Cape receiving the least (see figure 4.5).

Fig. 4.5: Scatter plot on the Distribution of Unconditional Transfers and Expenditure of State

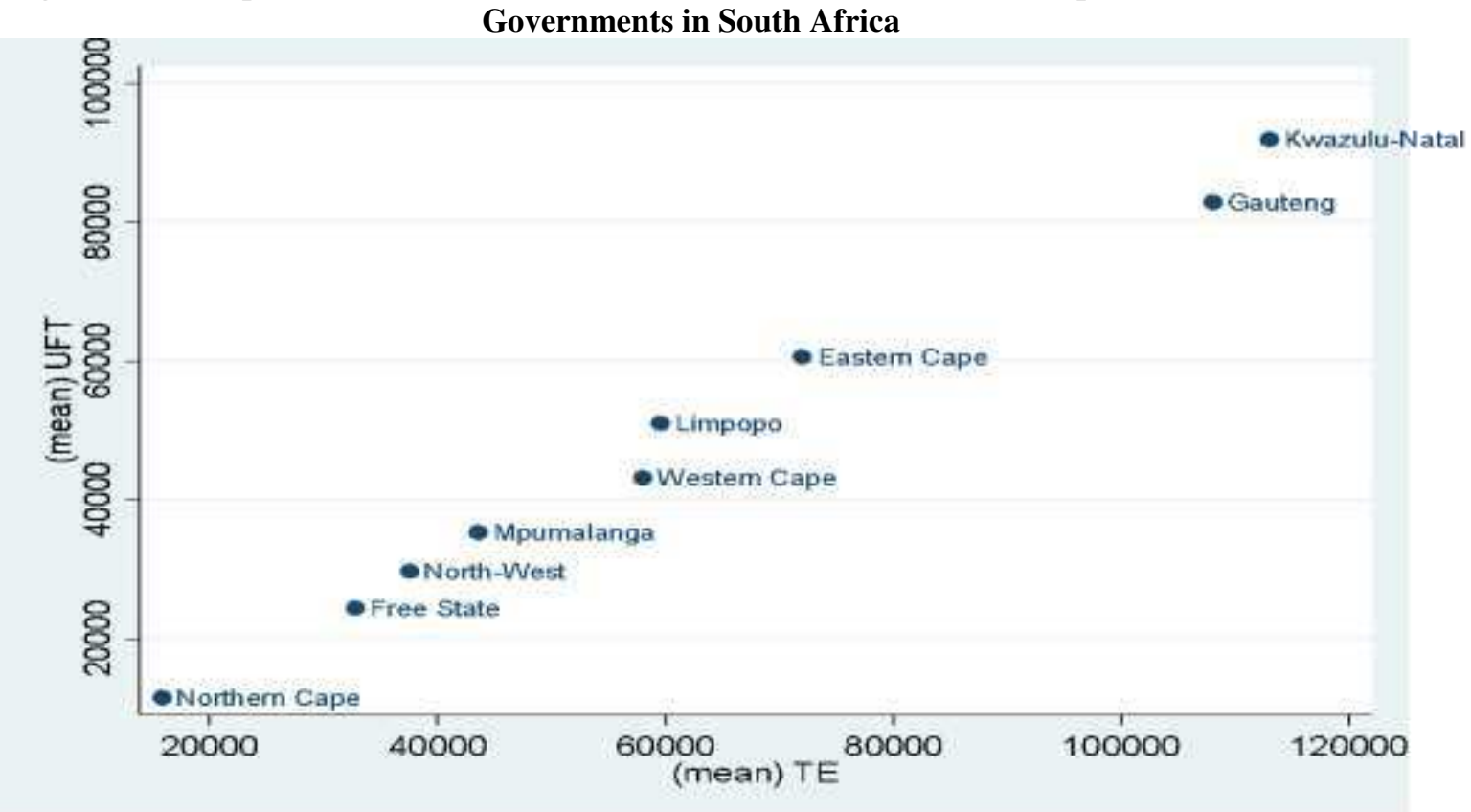

\subsubsection{Correlation Matrix}


The potential relationships between public spending of the state governments in Nigeria and the other variables are given in table 2. Those of South Africa are presented in table 3 . The correlation matrices point to the nature of the relationships to expect in the empirical analysis. It also corroborates the economic intuition behind the apriori expectations. All the variables exhibit positive relationships with public spending by the state and provincial governments in Nigeria and South Africa. Furthermore, all the variables exhibit positive relationships with one other except for the connection between public school enrollment and private personal income in both countries. The relationship between private personal income and state population is mixed, as it reveals a negative relationship for Nigeria but positive for South Africa.

Table 2: Correlation Matrix using Nigerian Data

\begin{tabular}{|c|c|c|c|c|c|c|}
\hline & TE & UFT & PPI & PSE & TR & POP \\
\hline TE & $\begin{array}{c}1.0000 \\
\end{array}$ & & & & & \\
\hline UFT & 0.6657 & 1.0000 & & & & \\
\hline PPI & 0.3002 & 0.2486 & 1.0000 & & & \\
\hline PSE & 0.1995 & 0.0385 & -0.1440 & 1.0000 & & \\
\hline TR & 0.7165 & 0.9757 & 0.3472 & 0.1266 & 1.0000 & \\
\hline POP & 0.1425 & -0.0102 & -0.2124 & 0.8552 & 0.0808 & 1.0000 \\
\hline
\end{tabular}

Table 3: Correlation Matrix using South African Data

\begin{tabular}{|c|c|c|c|c|c|c|}
\hline & TE & UFT & PPI & PSE & TR & POP \\
\hline TE & 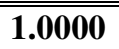 & & & & & \\
\hline UFT & 0.9940 & 1.0000 & & & & \\
\hline PPI & 0.1765 & 0.1044 & 1.0000 & & & \\
\hline PSE & 0.9111 & 0.9263 & -0.1427 & 1.0000 & & \\
\hline TR & 0.9989 & 0.9927 & 0.1709 & 0.9152 & 1.0000 & \\
\hline POP & 0.9405 & 0.9146 & 0.2131 & 0.8701 & 0.9467 & 1.0000 \\
\hline
\end{tabular}

The observed strong positive correlation between unconditional federal transfers and public spending vis-a-vis the correlation with private personal income, particularly, in South Africa appears to signal the presence of a flypaper effect in the spending behaviours of the state/provincial governments. The relationship between public spending and public revenue of the state/provincial governments is strong in both countries but it is relatively much stronger in South Africa. This is perhaps because of the reliance by South Africa on conventional means of raising revenue (taxes) in 
comparison to Nigeria's over-reliance on volatile oil revenues that tends to promote procyclical spending. The strong relationship between public school enrollment and public spending as well as unconditional federal transfers in South Africa seems to support the claim in the flypaper effect literature on the validity of public school enrollment as an instrumental variable in the expenditure function. The observed weak relationship in the case of Nigeria could be attributed to the relatively low percentage given to this principle in the revenue allocation formula.

\subsection{Analysis of the Flypaper Effect}

Our main interest in this study is to evaluate the behavior of the state/provincial spending to changes in unconditional or non-matching federal transfers and private personal income in Nigeria and South Africa towards verifying the existence or otherwise of the flypaper effect in the two largest economies in Sub-Saharan Africa (SSA). In line with the extant literature, the flypaper effect is interpreted in this study as the difference in elasticities of state or provincial government spending to a one percent change in unconditional federal transfers and private personal income, holding all other factors constant.

Table 4 presents the estimated results of equation 3.1. The dynamic panel regression model results and the long-run coefficients for Nigeria are reported in the second and third columns of table 4 , respectively. The results of the dynamic panel regression model and the long-run coefficients for South Africa are reported in the fourth and fifth columns, respectively. From the empirical results, we find that the one-period lag of state spending is a strong determinant of current spending by the state governments in Nigeria. This finding is a seeming attestation to our earlier claim that state spending in Nigeria tends to persist over time. We are, however, surprised about the observed non-persistence of public spending by provincial governments in South Africa. This perhaps opens another area of opportunity for future research as investigating the persistence of public spending in Nigeria and South Africa is clearly outside the scope of this study.

All things being equal, the results indicate that a one percent increase in unconditional federal transfers leads to a 0.268 percent increase in state spending in Nigeria in 
comparison to a 1.080 percent increase in provincial expenditure in South Africa. Both estimates are significant at the one percent level. Interestingly, we find that a one percent increase in private personal income (proxied by per capita own revenue) leads to a 0.110 percent and 0.129 percent increases in state and provincial spending in Nigeria and South Africa at the ten percent level of significance. The greater coefficients associated with unconditional federal transfers than with private personal incomes in both countries suggest the existence of a flypaper effect for non-matching transfers in the two largest economies of Sub-Saharan Africa. 
Table 4: Two-Steps System GMM Estimates [Dependent Variable: State/Provincial Total Expenditure (log)]

\begin{tabular}{|c|c|c|c|c|}
\hline \multirow[b]{2}{*}{ Variables } & \multicolumn{2}{|c|}{ Nigeria } & \multicolumn{2}{|c|}{ South Africa } \\
\hline & Dynamic Panel & $\bar{L} R$ Coefficients & Dynamic Panel & $\overline{\text { LR Coefficients }}$ \\
\hline \multirow[t]{2}{*}{ Constant } & $-37.79 *$ & na & 0.340 & na \\
\hline & $(21.53)$ & na & $(0.377)$ & na \\
\hline \multirow[t]{2}{*}{ Log total expenditure_1 } & $0.428 * *$ & 0.748 & -0.108 & na \\
\hline & $(0.175)$ & $(0.535)$ & $(0.127)$ & na \\
\hline \multirow[t]{2}{*}{ Log Unconditional Fed. Transfers } & $0.268 * *$ & $0.468 * * *$ & $1.080 * * *$ & $0.975 * * *$ \\
\hline & $(0.102)$ & $(0.085)$ & $(0.107)$ & $(0.064)$ \\
\hline \multirow[t]{2}{*}{ Log Private Personal Income } & $0.110^{*}$ & $0.192 *$ & $0.129 *$ & $0.117 * *$ \\
\hline & $(0.0541)$ & $(0.101)$ & $(0.062)$ & $(0.049)$ \\
\hline \multirow[t]{2}{*}{ Log Public School Enrolment } & $0.0539 * *$ & $0.094 * *$ & -0.021 & na \\
\hline & $(0.0246)$ & $(0.040)$ & $(0.056)$ & na \\
\hline Number of Observations & 154 & na & 63 & na \\
\hline Time Dummies & Yes & na & Yes & na \\
\hline Number of Groups & 22 & na & 9 & na \\
\hline Number of Instruments & 18 & na & 9 & na \\
\hline F-Statistic & 376456.69 & na & 923722.72 & na \\
\hline GMM Instrument Lag & 1 & na & 1 & na \\
\hline $\operatorname{AR}(1)$ & 0.040 & na & 0.204 & na \\
\hline $\operatorname{AR}(2)$ & 0.103 & na & 0.215 & na \\
\hline Hansen test & 0.248 & na & 0.361 & na \\
\hline
\end{tabular}

Note that the estimations are done using STATA 17.0 and the xtabond2 command which is routine under the two-steps system GMM estimation technique. The Robust options is used after conducting various alternative simulations; Standard errors are in parentheses; $* * * p<0.01, * * p<0.05, * p<0.1$ denote significance level at $1 \%$, 5\% and $10 \%$, respectively. Source: Authors computations. na=not applicable. 
The flypaper effect ${ }^{6}$ estimated for Nigeria at 0.158 is far lower than the 0.951 established for South Africa. We find the elasticity of expenses by provincial governments to a one percent change in unconditional or non-matching federal transfers in South Africa to be elastic while that of the state governments in Nigeria is inelastic. The greater elasticity of expenditure to changes in unconditional federal transfers in South Africa suggests that the provincial governments respond more to changes in unconditional federal transfers than do state governments in Nigeria. This further suggests that the provincial indigenes in South Africa are more informed about unconditional federal transfers such that the illusion level or information asymmetry associated with non-matching transfers in South Africa is less than what obtains at the state level in Nigeria. This may not be unconnected with the disclosure issues surrounding the amount of unconditional transfers received by the state governments. The Hansen tests of over-identification restriction reveal that the instrument sets are not over-identified, while the results of the specification tests $[\operatorname{AR}(2)]$ indicate that the models are free from second order serial correlation. This implies that valid inferences can be drawn from the empirical results.

The LR coefficients reported in table 5.1 above reveal that unconditional federal transfers have significantly larger effects on state spending in Nigeria but a significantly smaller effects on provincial spending in South Africa in the long-run, all things being equal. The LR flypaper effect estimated for South Africa (0.858) is substantially larger than the effect estimated for Nigeria (0.276). This implies that the provincial authorities in South Africa are more responsive to changes in unconditional federal transfers than the state authorities in Nigeria in terms of the supply of public goods when faced with more revenue resources. The above finding is indeed not surprising given the corruption perception index of the two countries and the fact that the level of corruption appears to be more at the subnational levels.

On average, a one percent increase in unconditional federal transfers is, in the LR, associated with 0.468 and 0.975 percent increase in state/provincial spending in Nigeria and South Africa at the one percent level of significance, ceteris paribus. Thus, unconditional federal transfers and public spending at the state/provincial level

\footnotetext{
${ }^{6}$ The flypaper effect is the difference in elasticities of state/provincial spending to an increase in nonmatching transfers and that of private income.
} 
exhibit an inelastic LR relationship in both Nigeria and South Africa. While the LR impact is larger for Nigeria it is found to be smaller for South Africa.

\subsection{Robustness Checks}

We conduct robustness checks on the results; first, using alternative measures of the state or provincial spending and second by expressing all the variables in per capita terms to see if compensating for the differences in size of the states or provinces will affect the results in any significant way. We also estimate the model using alternative estimators such as the pooled OLS, fixed-effects and random effects estimators in order to verify if the results are sensitive to the choice of estimator. 
Table 5: Robustness Checks [Using Alternative Measures of State/Provincial Govt. Expenditure]

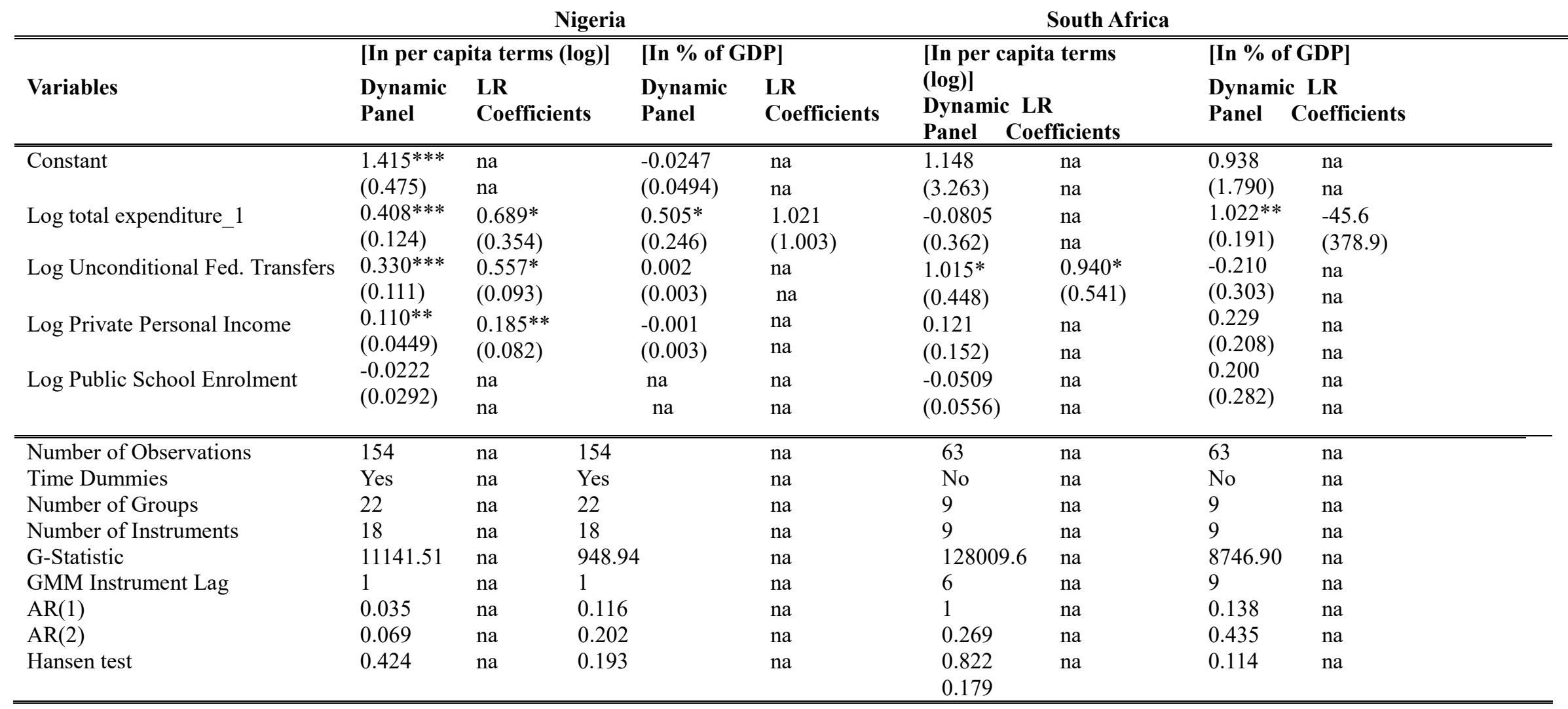

Note that the estimations are done using STATA 17.0 and the xtabond 2 command which is routine under the two-steps system GMM estimation technique. The Robust options is used after conducting various alternative simulations; Standard errors in parentheses; *** $\mathrm{p}<0.01, * * \mathrm{p}<0.05, * \mathrm{p}<0.1$ denote significance level at $1 \%, 5 \%$ and $10 \%$, respectively. Source: Authors' computations. na=not applicable. 
Table 5 clearly indicates that the flypaper effect is sensitive to model specification as the results in table 4.1 differ widely from the results in table 5 when control measures are considered such as expressing all the variables in per capita terms and when a different measure of the dependent variable (expressed as \% of GDP) is adopted. Though state spending is still established to be persistent in Nigeria and the existence of a flypaper effect is also established in both the short- and long-run, the elasticity of state spending to a one percent increase in unconditional federal transfers is found to have increased to 0.330 but that of private personal income remains the same. We, however, could not establish the presence of a flypaper effect for South Africa in both the short-and long-run using these alternative specifications.

From the results of the alternative estimators reported in table 6 , the outcome of the Hausman test indicates 0.938 in the case of Nigeria, implying that we cannot reject the Null Hypothesis $\left(\mathrm{H}_{0}\right)$ which says that the random effects are independent of the explanatory variables. This further implies that the estimator of best fit in the case of Nigeria is the random-effects estimator (panel 3 of table 6). In the case of South Africa, the result of the Hausman test indicates 0.000 , implying a rejection of $\mathrm{H}_{0}$ which means that the random effects are correlated with the explanatory variables and, therefore, the model of best fit in the case of South Africa is the fixed-effects model (panel 5 of table 6). 
Table 6:Robustness Checks Using Alternative Estimators [Dependent variable is the State/Provincial Govt. Expenditure]

\begin{tabular}{|c|c|c|c|c|c|c|}
\hline \multirow[b]{3}{*}{ Variables } & \multicolumn{3}{|c|}{ Nigeria } & \multicolumn{3}{|c|}{ South Africa } \\
\hline & (1) & (2) & (3) & (4) & (5) & (6) \\
\hline & $\begin{array}{l}\text { Pooled } \\
\text { OLS }\end{array}$ & FE & RE & $\begin{array}{l}\text { Pooled } \\
\text { OLS }\end{array}$ & FE & $\mathrm{RE}$ \\
\hline Constant & $\begin{array}{l}8.371^{* * *} \\
(1.215)\end{array}$ & $\begin{array}{l}9.238^{*} \\
(5.357)\end{array}$ & $\begin{array}{l}8.982 * * * \\
(2.361)\end{array}$ & $\begin{array}{c}0.797 * * * \\
(0.192)\end{array}$ & $\begin{array}{l}2.314 * * * \\
(0.350)\end{array}$ & $\begin{array}{l}0.919 * * * \\
(0.263)\end{array}$ \\
\hline $\begin{array}{l}\text { Log Unconditional Fed. } \\
\text { Transfers }\end{array}$ & $\begin{array}{c}0.537 * * * \\
(0.061)\end{array}$ & $\begin{array}{c}0.387 \\
(0.259)\end{array}$ & $\begin{array}{c}0.451 * * * \\
(0.114)\end{array}$ & $\begin{array}{r}0.884 * * * \\
(0.038)\end{array}$ & $\begin{array}{l}0.638 * * * \\
(0.064)\end{array}$ & $\begin{array}{l}0.865^{* * *} \\
(0.051)\end{array}$ \\
\hline Log Private Personal Income & $\begin{array}{r}0.118 * * * \\
(0.042)\end{array}$ & $\begin{array}{l}0.285 * * * \\
(0.069)\end{array}$ & $\begin{array}{l}0.233 * * * \\
(0.055)\end{array}$ & $\begin{array}{c}0.162 * * * \\
(0.023)\end{array}$ & $\begin{array}{l}0.006 \\
(0.035)\end{array}$ & $\begin{array}{l}0.138 * * * \\
(0.030)\end{array}$ \\
\hline Log Public School Enrollment & $\begin{array}{l}0.086 * * \\
(0.036) \\
\end{array}$ & $\begin{array}{l}0.210 * * \\
(0.103) \\
\end{array}$ & $\begin{array}{l}0.144 * * \\
(0.063) \\
\end{array}$ & $\begin{array}{l}0.0642 * \\
(0.036) \\
\end{array}$ & $\begin{array}{l}-0.276 \\
(0.181) \\
\end{array}$ & $\begin{array}{l}0.078 \\
(0.050) \\
\end{array}$ \\
\hline $\mathrm{N}$ & 176 & 176 & 176 & 72 & 72 & 72 \\
\hline $\mathrm{R}^{2}$ & 0.462 & 0.401 & 0.438 & 0.997 & 0.821 & 0.996 \\
\hline Year FE & No & Yes & Yes & Yes & Yes & Yes \\
\hline State/Province FE & No & Yes & No & No & Yes & No \\
\hline Number of Groups & 22 & 22 & 22 & 9 & 9 & 9 \\
\hline Hausman test & na & na & 0.938 & na & na & 0.000 \\
\hline
\end{tabular}


Based on the results of the models of choice (panels 3 and 5 of table 6), we find that the results are also sensitive to the choice of estimator as the estimation results of the random-effects estimator indicate the existence of the flypaper effect at the state level in Nigeria but the estimation results of the fixed-effects estimator could not confirm the results of the two-step SGMM estimator that the flypaper effect exists at the provincial level in South Africa.

\subsection{Conclusion}

In view of the scarce literature on the flypaper effect at the country level in SubSaharan Africa (SSA), this study employs a sample of 22 out of the 36 states in Nigeria and the nine provinces of South Africa to investigate the existence or otherwise of the flypaper effect in the two countries. Being the first attempt at providing empirical evidence on the existence of the flypaper effect in the two largest economies in SSA, the study contributes to the flypaper effect literature by employing a more robust estimation technique (the two-step system GMM estimator) that improves the precision of the parameter estimates towards providing empirical evidence that the flypaper effect exists at both the state and provincial levels in Nigeria and South Africa. We also provide empirical evidence that the flypaper effect exists in Nigeria and South Africa in both the short-and long-run, and that the flypaper effect for the provincial governments in South Africa is substantially larger than that of the state governments in Nigeria.

We further established evidence on the persistence of state spending in Nigeria and the lack of it in South Africa. Since the persistence or non-persistence of state spending is not the central focus of this paper, we wish to recommend for further research in this area as a more detailed investigation on the persistence of provincial spending in South Africa will throw more light on the persistence of public spending in both countries. As more information unfolds in the future, another area of research that may attract the interest of scholars is in testing for the existence of the flypaper effect with regards to conditional or matching transfers in both countries. Based on our finding that provincial authorities in South Africa are more responsive to changes in unconditional federal transfers than the state authorities Nigeria, there may be need for Nigeria to upscale sensitization on the receipts and disbursements of unconditional federal transfers in their jurisdictions towards a reduction in the illusion level or 
information asymmetry about the use of unconditional federal transfers to enhance the benefits that are derivable from the use of state resources, particularly, the procurement of public goods and services. Given that the elasticity of state or provincial spending in both countries is large, it is our conviction that an increase in unconditional federal transfers will immensely benefit the indigenes in terms of the higher supply of public goods and services.

\section{Declaration}

\section{Data Availability Statement}

The datasets used and/or analysed during the current study are available from the corresponding author on reasonable request.

\section{Competing interests}

The authors declare that they have no competing interests.

\section{Funding}

The authors received no funding for the research.

\section{Authors' contributions}

Abdurrahman Isik: Writing - original draft, writing- review \& editing, Validation, Visualization, Supervision.

Peter D. Golit: Conceptualization, writing -original draft, formal analysis, investigation, methodology.

Paul Terhemba Iorember: Data curation, Writing -original draft, Writing- review \& editing, formal analysis, formatting.

\section{Acknowledgements}

The authors are very grateful to Dr Nargiza Alymkulova - Head, Department of Economics, Nile University, and Dr. Michael Adebayo Adebiyi - Director, Research Department, Central Bank of Nigeria for providing the necessary encouragement and moral support, and for editing the final draft of the manuscript. 


\section{Authors' information}

Abdulrahaman Isik is a professor of Economics and the Deputy Vice Chancellor (Academics), Nile University of Nigeria, Abuja, Nigeria.

Peter D. Golit is a PhD Student, Economics Department, Nile University of Nigeria, Abuja, Nigeria. He is also a Principal Manager with the Research Department, Central Bank of Nigeria, Abuja, Nigeria.

Paul Terhemba Iorember is a Lecturer and Senior Researcher at the Department of Economics, Nile University of Nigeria.

\section{References}

Allers, M. A., Vermeulen, W., 2016. Capitalization of equalizing grants and the flypaper effect. Regional Science and Urban Economics, 58, 115-129.

Acosta, P., and Loza, A., 2001. Burocracia y federalismo fiscal: un marco teórico para el análisis del efecto "flypaper" in Sour, L. (2013). The Flypaper Effect in Mexican Local Governments. Estudios Económicos, Enero-Junio, Vol. 28, No. 1(55), pp. 165-186. https://www.jstor.org/stable/23609654.

Arellano, M., Bond, S., 1991. Some Tests of Specification for Panel Data: Monte Carlo Evidence and an Application to Employment Equations. Rev. Econ. Stud. 58 (2), 277-297.

Baskaran, T., 2016. Intergovernmental Transfers, Local Fiscal Policy, and the Flypaper Effect: Evidence from a German State. FinanzArchiv: Public Finance Analysis 72, 1-40.

Becker, Elizabeth, 1996. The illusion of fiscal illusion: Unsticking the flypaper effect. Public Choice 86, 85-102.

Besley, T., Coate, S., 2003. Centralized versus decentralized provision of local public goods: a political economy approach. Journal of Public Economics 87, 2611-2637.

Blackburne, E. F. and Frank, M.W., 2007. Estimation of Nonstationary Heterogeneous Panels. Stata J. 7 (2), 197-208.

Blöchliger, H. and Charbit, C., 2008. Fiscal Equalisation by OECD Economic Studies. No. 44/1, OECD.

Bradford, D. F. and Oates, W. E., 1971. Towards a Predictive Theory of Intergovernmental Grants, The American Economic Review, 61(2): 440-44

Bradford, D.F. and Oates, W.E., 1971b. The Analysis of Revenue Sharing in a New Approach to Collective Fiscal Decisions. Quarterly Journal of Economics, Vol.85, p.434. 
Brollo, F., Nannicini, T. Perotti, R., and Tabellini, G., 2013. The political resource curse. American Economic Review 103, 1759-1796.

Cruz, T. and Silva, T. (2020). Minimum Spending in Education and the Flypaper

Effect. Economics of Education Review 77, 102012.

Dahlberg, M., Mork, E., Rattsø, J. and Agren, H., 2008. Using a discontinuous grant rule to identify the effect of grants on local taxes and spending. Journal of Public Economics 92, 2320-2335.

Darby, J., Muscatelli, A., Roy, G., 2005. Fiscal Consolidation and decentralization: a tale of two tiers. Fiscal studies 26 (2), 169-195.

De Mello, L., 2000. Fiscal decentralization and intergovernmental fiscal relations: a cross-country analysis. World Development 28 (2), 365-380.

Dollery, B. E., and Worthington, A. C., 1996. The empirical analysis of fiscal illusion. Journal of Economic Surveys 10, 261-297

Espinosa, S. 2011. Mexican Flypaper: Money Sticks Where it Hits...But Every Time? Latin American Policy, 2(2): 122-136

Epple, D., Nechyba, T., 2004. Fiscal decentralization. In: Henderson, J.V., Thisse, J.F. (Eds.), Handbook of Regional and Urban Economics, vol. 4.

Eyraud, L., \& Lusinyan, L., 2013. Vertical fiscal imbalances and fiscal performance in advanced economies. Journal of Monetary Economics, 60, 571-587.

Faguet, J-P., 2004. Does decentralization increase government responsiveness to local needs? Evidence from Bolivia. Journal of Public Economics, 88(3-4), 867-93.

Ferede, E., and Islam, S., 2015. Block Grants and Education Expenditure: Evidence from Canadian Provinces. Public Finance Review 44, 635-659.

Fornasari, F., Webb, S. B., Zou, H., 2000. The macroeconomic impact of decentralized spending and deficits: international evidence. Annals of Economics and Finance 1, 403-433.

Gamkhar, S. 2000. Is the Response of State and Local Highway Spending Symmetric to Increases and Decreases in Federal Highway Grants? Public Finance Review, 28(1): 3-25.

Gramlich, E.M., Galper, H., 1973. State and Local Fiscal Behavior and Federal Grant Policy. Brookings Papers on Economic Activity, Vol.1, pp.15-58.

Grossman, Phillip J., 1990. The Impact of Federal and State Grants on Local Government Spending: a Test of the Fiscal Illusion Hypothesis. Public Finance Review 18, 313-327.

Hamilton, B., 1983. The Flypaper Effect and Other Anomalies. Journal of Public Economics 22, 347-361. 
Hines, J. R., and Thaler, R. H., 1995. Anomalies: The Flypaper Effect. Journal of Economic Perspectives 9, 217-226.

Hobdari, N., Nguyen, V., Dell'Erba, S. and Ruggiero, E. (2018). Lessons for Effective Fiscal Decentralization in Sub-Saharan Africa. Departmental Paper Series, African “ Department, International Monetary Fund (IMF), No. 18/10, ISBN 9781484358269 (paper).

IMF (2009). Macro policy lessons for a sound design of fiscal decentralization. IMF, Washington D. C.

Inman, R. P. (2008). The Flypaper Effect. Working Paper 14579. National Bureau of Economic Research. https://doi.org/10.3386/w14579.

Jin, J., Zou, H.-F., 2002. How does fiscal decentralization affect aggregate, national, and subnational government size? Journal of Urban Economics 52, 270-293.

Knight, B., 2002. Endogenous Federal Grants and crowd-out of state government spending: Theory and evidence from the federal highway aid program. American Economic Review 92, 71-92.

Langer, S. and Korzhenevych, A., 2019. Equalization Transfers and the Pattern of Municipal Spending: An Investigation of the Flypaper Effect in Germany. Annals of Economics and Finance 20-2, 737-765.

Liu, Y. and Zhao, J., 2011. Intergovernmental fiscal transfers and local tax efforts: evidence from provinces in China." Journal of Economic Policy Reform, 14(4), 295-300.

Logan, R. R., 1986. Fiscal Illusion and the Grantor Government. Journal of Political Economy 94, 1304-1318.

Martinez-Vazquez, J. and Sepulveda, C., 2018. A Theoretical Rationale for the Fiscal Gap Model of Equalization Transfers. International Center for Public Policy. Working Paper 18-23, November.

Niskanen, W. (1968). The Peculiar Economics of Bureaucracy. The American Economic Review, 58(2): 293-305.

Oates, W., 2006. On theory and practice of fiscal decentralization. IFIR Working Paper Series 2006-05. Institute for Federalism and Intergovernmental Relations, Lexington.

Rodden, J., 2003. Reviving Leviathan: Fiscal Federalism and the growth of government. International Organization 57 (Fall), 695-729.

Rodden, J., Eskeland, G. S., Litvack, J., 2003. Fiscal decentralization and the challenges of hard budget constraint. MIT Press, Cambridge, MA.

Sağbaş, I. and Saruç, N. T., 2007. Intergovernmental Transfers and the Flypaper Effect in Turkey. Turkish Studies, 5:2, 79-92. 
Sharma, C. K., 2012. Beyond gaps and imbalances: restructuring the debate on intergovernmental fiscal relations. Public Administration 90 (1), 99-128.

Singhal, M., 2008. Special interest groups and the allocation of public funds. Journal of Public Economics 92, 548-564.

Sour, L. (2013). The Flypaper Effect in Mexican Local Governments. Estudios Económicos, Enero-Junio, Vol. 28, No. 1(55), pp. 165-186. https://www.jstor.org/stable/23609654.

Tanjunga, A. H.; Salamb, S.; Rusdi, J. F.; Ermawati, Y.; Novianty, I.; Hendaris, R. B. and Apriliawati, Y. (2021). Flypaper Effect Assessment Methods in the Expansion of Regional Autonomy. MethodsX 8, 101387. https://doi.org/10.1016/j.mex.2021.101387

Turnbull, G. K. (1998). The Overspending and Flypaper Effects of Fiscal Illusion: Theory and Empirical Evidence. Journal of Urban Economics 44, 1-26, No. UE972056.

Von Hagen, J., Eichengreen, B., 1996. Federalism, fiscal restraints, and European Monetary Union. The American Economic Review 86 (2). Papers and Proceedings of the Hundredth and Eighth Annual Meeting of the American Economic Association.

Wyckoff, P. G., 1988. A bureaucratic theory of flypaper effects. Journal of Urban Economics 23, 115-129 